(c) American Dairy Science Association, 2003.

\title{
Influence of Proteolysis of Milk on the Whey Protein to Total Protein Ratio as Determined by Capillary Electrophoresis
}

\author{
B. Miralles, M. Ramos, and L. Amigo \\ Instituto de Fermentaciones Industriales (CSIC) \\ Juan de la Cierva, 3, E-28006 Madrid, Spain
}

\begin{abstract}
Capillary electrophoresis (CE) was used to determine the whey protein to total protein ratio in raw and UHT milk samples with different degrees of proteolysis caused by storage. In raw milks, the analysis of samples taken at regular times demonstrated the influence of proteolysis in the whey protein to total protein determination, which was overestimated after $4 \mathrm{~d}$ of storage. In UHT milks, the overestimation of the whey protein to total protein ratio took place after 30 or $60 \mathrm{~d}$ of storage. However, the ratios $\alpha_{\mathrm{S} 1}-\mathrm{CN} / \beta-\mathrm{CN}$ and $\alpha_{\mathrm{s} 1}-\mathrm{CN} /$ $\kappa$-CN permitted detection of the samples of raw or UHT milk with degraded proteins. The distorted capillary electrophoretic pattern obtained for UHT milks made necessary an integration of the electropherograms in a "valley-to-valley" way. Results for raw milk samples were identical when "valley-to-valley" was compared to standard integration techniques. This CE method could be considered an alternative method to derivative spectroscopy for the determination of the whey protein to total protein of milk and could be used to detect samples with proteolysis.
\end{abstract}

(Key words: whey protein to total protein ratio, proteolysis, processed milk, capillary electrophoresis)

Abbreviation key: $\mathbf{C E}=$ capillary electrophoresis, $\alpha$ $\mathbf{L a}=\alpha$-lactalbumin, $\boldsymbol{\beta}$ - $\mathbf{L g}=\beta$-lactoglobulin, $\mathbf{N C N}=$ noncasein nitrogen content, $\mathbf{T N}=$ total nitrogen content .

\section{INTRODUCTION}

The whey protein to total protein ratio is an important parameter in milk and dairy products, not only to evaluate the technological treatments applied but also to detect fraudulent additions of protein. When protein standardization was first considered, there was a concern that protein concentrations could be reduced by the addition of whey-based materials (Burgess,

Received January 2, 2003.

Accepted March 13, 2003.

Corresponding author: L. Amigo; e-mail: amigo@ifi.csic.es.
1997). To evaluate whether the adjustments in protein in milk keep the natural whey protein to total protein ratio, this value should be established and methods permitting its determination should be available. Due to the interest of this subject, the Group of Experts in Milk and Dairy Products of the European Union is studying the introduction of a method with this purpose.

Two spectroscopic methods based in the zero and first-order derivative have been developed (De Block et al., 1997) and applied to detect whey powder in milk powder (Cartuyvels et al., 1999). A fourth derivative spectroscopy method (Meisel, 1995) has proved its suitability for the determination of the whey protein to total protein ratio in raw milks (Lühti-Peng and Puhan, 1999) as well as in milk samples submitted to different heat treatments (Miralles et al., 2000a). One of the features of this method is not to be influenced by the protein conformation.

Two different capillary electrophoresis $(\mathbf{C E})$ methods (SDS-CE and CE) have been compared with the fourthderivative spectroscopy in the analysis of raw, pasteurized, and UHT milks (Miralles et al., 2000b). Values obtained were similar by using the three methods, but the pattern obtained with $\mathrm{CE}$ provided additional information about the milk proteins state. That paper stressed the importance of carrying out further studies to determine whether different proteolysis degrees caused by storage of milk could alter the results obtained by CE. The aim of this study has been to go deeply into the $\mathrm{CE}$ determination of the whey protein to total protein ratio by analyzing raw and heat-treated milk submitted to storage, where proteolysis can be present.

\section{MATERIALS AND METHODS}

\section{Samples}

The NISECAS set consisting of five lyophilized mixtures of serum protein solution and casein milk obtained by membrane filtration with a whey protein to total protein ratio $0,15,20,25$, and 100 from NIZO 
Food Research (Ede, Netherlands) were used as reference samples.

To study the effect of storage, four raw milk samples were kept during $4 \mathrm{~d}$ at $6^{\circ} \mathrm{C}$ in refrigerated industrial containers and samples were taken at 0,2 and $4 \mathrm{~d}$. These samples were assayed for their bacterial count. Viable counts were performed by spiral plating technique (AOAC, 1990) using milk agar (Difco, Detroit, $\mathrm{MI}$ ), with the plates being incubated at $30^{\circ} \mathrm{C}$ for $24 \mathrm{~h}$ for mesophilic and at 6 to $8^{\circ} \mathrm{C}$ for $7 \mathrm{~d}$ for psychrotroph counts. Two samples of skimmed milk from different dairy industries were collected before and after an indirect UHT treatment $\left(137^{\circ} \mathrm{C}, 4 \mathrm{~s}\right)$. Ultra-high temperature milk samples were stored at room temperature $\left(25^{\circ} \mathrm{C}\right)$ for up to $90 \mathrm{~d}$ and analyzed every $30 \mathrm{~d}$. Moreover, 20 samples of raw milk and 20 samples of whole and skimmed commercial UHT milk were taken.

\section{Protein Analysis}

Total nitrogen content (TN), noncasein nitrogen content (NCN) corresponding to the milk soluble fraction at $\mathrm{pH} 4.6$, and NPN content corresponding to the nonprecipitated fraction with $12 \%$ trichloroacetic acid were determined by the Kjeldahl method following the IDF Standard 20B (1993).

\section{Capillary Electrophoresis}

The CE separations were performed with a Beckman P/ACE System MDQ using an hydrophylically coated fused-silica capillary column CElect P1 (Supelco, Bellefonte, PA) $600 \mathrm{~mm} \times 50 \mu \mathrm{m} \mathrm{I}$. D. with a slit opening of $100 \times 800 \mu \mathrm{m})$. The electrophoresis buffer consisted of a solution of $0.19 M$ citric acid and $20 \mathrm{~m} M$ trisodium citrate (Sigma, St. Louis, MO) in $6 M$ urea solution with methylhdrosyethyl cellulose $30000(0.5 \mathrm{~g} / \mathrm{L}$, Serva D69042 Heidelberg, Germany) ( $\mathrm{pH} 3.0 \pm 0.05$ ), as reported by Recio and Olieman (1996). The sample buffer consisted of $167 \mathrm{~m} M$ Tris (Sigma), $42 \mathrm{mM}$ 3-morpholinopropanesulphonic acid (Biochemica MicroSelect, Fluka CH 9470 Buchs, Switzerland), $67 \mathrm{mM}$ ethylenedinitrilo tetraacetic acid disodium salt (Titriplex III, Merck, D64271 Darmstadt, Germany, $17 \mathrm{mM}$ DL-dithiothreitol (Sigma) in urea solution (pH $8.6 \pm 0.05)$.

The whey protein to total protein was determined as the quotient between the area percentages values of BSA plus $\alpha$-lactalbumin ( $\alpha$-La) plus $\beta$-lactoglobulin $(\beta$ $\mathbf{L g}$ ), and the area of all the electrophoretic peaks detected (relative peak area of total serum protein expressed as a percentage). The $\alpha_{\mathrm{s} 1}-\mathrm{CN} / \beta-\mathrm{CN}$ quotient was calculated by dividing the area of $\alpha_{\mathrm{s} 1}-\mathrm{CN}$ by the sum of the $\beta$-CN $\mathrm{A}^{1}$ and $\mathrm{A}^{2}$ areas. The $\alpha_{\mathrm{s} 1}-\mathrm{CN} / \kappa-\mathrm{CN}$ quotient was calculated by dividing the area of $\alpha_{\mathrm{s} 1}-\mathrm{CN}$

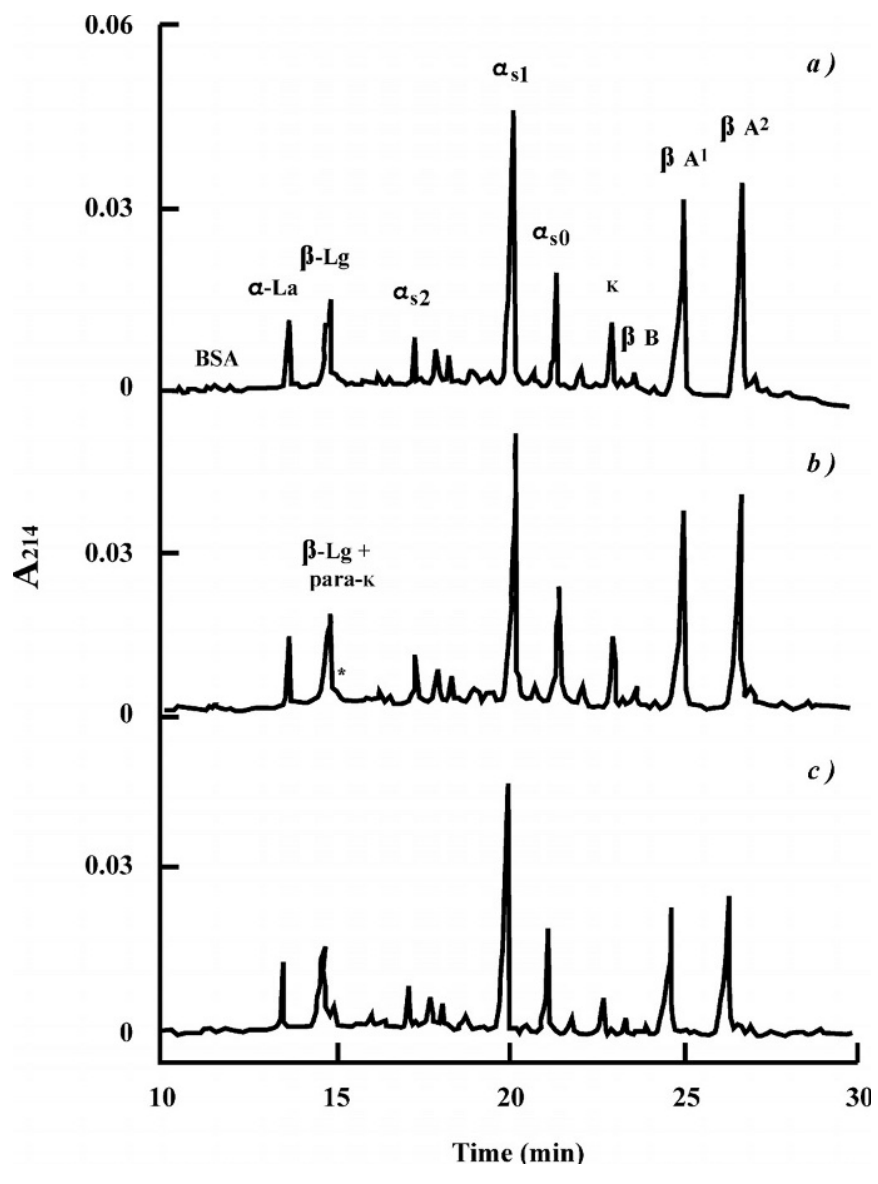

Figure 1. Electropherograms of samples of raw milk stored at $6^{\circ} \mathrm{C}$ for a) 0, b) 2 and c) 4 d. BSA: Bovine serum albumin, $\alpha$-La: $\alpha$ Lactalbumin, $\beta$-Lg: $\beta$-Lactoglobulin, $\alpha_{\mathrm{s} 2}: \alpha_{\mathrm{s} 2}$-casein $(\mathrm{CN}), \alpha_{\mathrm{s} 1}: \alpha_{\mathrm{s} 1}-\mathrm{CN}$, $\alpha_{\mathrm{s} 0}: \alpha_{\mathrm{s} 0}-\mathrm{CN}, \kappa: \kappa-\mathrm{CN}, \beta \mathrm{B}: \beta-\mathrm{CN} \mathrm{B}, \beta \mathrm{A}^{1}: \beta-\mathrm{CN} \mathrm{A}^{1}, \beta \mathrm{A}^{2}: \beta-\mathrm{CN} \mathrm{A}{ }^{2}$.

by the area of $\kappa$-CN. All samples were analyzed at least by duplicate.

\section{RESULTS AND DISCUSSION}

\section{Effect of Refrigerated Storage of Raw Milk}

Refrigerated storage of raw milk is usual before industrial processing, although it permits psychrotrophic bacteria to grow and proteinases to be produced (Grieve and Kitchen, 1985). Proteolysis of milk affects the separation of proteins by CE because the size of some peaks is reduced and new products arise (Recio et al., 1997). This is expected to affect the determination of the whey protein to total protein ratio. To ascertain this, raw milk was analyzed by $\mathrm{CE}$ after 0,2 , and $4 \mathrm{~d}$ of refrigerated storage (Figure 1). It can be observed that the height of $\kappa-\mathrm{CN}, \beta-\mathrm{CN} \mathrm{A}^{1}$, and $\beta$ - $\mathrm{CN} \mathrm{A}^{2}$ is reduced while para- $\kappa-\mathrm{CN}$ appears. Under these conditions, para- $\kappa-\mathrm{CN}$ has a migration time very close to that of $\beta-\mathrm{Lg}$ (Otte et al., 1997), which produces an apparent widening of the 
Table 1. Determination of the ratios whey protein to total protein (WP/TP), $\alpha_{\mathrm{s} 1}-\mathrm{CN} / \kappa$-CN, and $\alpha_{\mathrm{s} 1}-\mathrm{CN} / \beta$-CN and mesophilic and psychrotrophic counts in samples of raw milk stored at $6^{\circ} \mathrm{C}$ during 0,2 and $4 \mathrm{~d}$ by capillary electrophoresis $(\mathrm{n}=4)$.

\begin{tabular}{|c|c|c|c|c|c|}
\hline Storage time $(\mathrm{d})$ & $\mathrm{WP} / \mathrm{TP}$ ratio $^{1}(\%)$ & $\begin{array}{l}\text { Mesophiles count }{ }^{1} \\
\quad(\log \mathrm{cfu} / \mathrm{ml})\end{array}$ & $\begin{array}{l}\text { Psychrotrophs count }{ }^{1} \\
\quad(\log \mathrm{cfu} / \mathrm{ml})\end{array}$ & $\begin{array}{c}\alpha_{\mathrm{s} 1}-\mathrm{CN} / \beta-\mathrm{CN}^{1} \\
\text { ratio }\end{array}$ & $\begin{array}{c}\alpha_{\mathrm{s} 1}-\mathrm{CN} / \kappa-\mathrm{CN}^{1} \\
\text { ratio }\end{array}$ \\
\hline 0 & $16.8^{\mathrm{a}} \pm 0.1$ & $4.59^{\mathrm{a}} \pm 0.58$ & $4.01^{\mathrm{a}} \pm 1.04$ & $0.59^{\mathrm{a}} \pm 0.01$ & $4.2^{\mathrm{a}} \pm 0.28$ \\
\hline 2 & $17.9^{\mathrm{a}} \pm 0.4$ & $6.17^{\mathrm{b}} \pm 1.27$ & $5.74^{\mathrm{b}} \pm 1.59$ & $0.62^{\mathrm{a}} \pm 0.02$ & $4.2^{\mathrm{a}} \pm 0.24$ \\
\hline
\end{tabular}

${ }^{1}$ Same letter $(\mathrm{a}, \mathrm{b})$ in the same column means absence of significant differences $(P<0.05)$.

last peak. In UHT milk, the presence of minor forms of para- $\kappa$-CN produced by the action of thermoresistant proteases that remain in milk has been described (Snoeren et al., 1979; López-Fandiño et al., 1993). The amount of these proteases depends on its presence in the original milk, probably being associated to raw milk of poor microbial quality. The most susceptible proteins to the action of these bacterial proteases are $\kappa$-CN and $\beta$-CN (Grieve and Kitchen, 1985; Miranda and Gripon, 1986). On the contrary, $\alpha_{\mathrm{s} 1}-\mathrm{CN}$ is much less sensitive to proteolysis (Swaisgood, 1992).

Table 1 shows the values of the whey protein to total protein ratio of the analyzed samples. At $4 \mathrm{~d}$ of storage, the ratio was significantly $(P<0.05)$ higher due to the overestimation of the area of $\beta-\mathrm{Lg}$ and the reduced size of the caseins. With the aim to estimate the proteolysis of the milk, which was suspected by the mesophilic and psycrotrophic counts (Table 1), a relative measure of the degradation of $\beta$ - and $\kappa$-CN was made by calculating the ratios $\alpha_{\mathrm{s} 1}-\mathrm{CN} / \kappa-\mathrm{CN}$ and $\alpha_{\mathrm{s} 1}-\mathrm{CN} / \beta$-CN. It can be observed that values of both ratios were significantly higher at $4 \mathrm{~d}$ of storage. Values obtained for the ratio $\alpha_{\mathrm{s} 1}-\mathrm{CN} / \kappa-\mathrm{CN}$ had a wide dispersion, which can be due to the different content in psychrotrophic bacteria in the different samples, or to their different activity; it is known that depending, on the strain, psychrotrophic bacteria produce different amounts of proteolytic enzymes (Renner, 1988). Both ratios were considered adequate indexes for estimating the degree of proteolysis of raw milk. To assess these indexes, they were calculated in 20 bulk raw milk samples. The average $\alpha_{\mathrm{s} 1^{-}}$ $\mathrm{CN} / \kappa-\mathrm{CN}$ ratio was $3.9 \pm 0.6$, the quotients in the range 2.9 to 4.7. The average $\alpha_{\mathrm{s} 1}-\mathrm{CN} / \beta-\mathrm{CN}$ was $0.60 \pm 0.6$, the quotients in the range 0.46 to 0.68 . Thus, raw milks with $\alpha_{\mathrm{s} 1}-\mathrm{CN} / \kappa-\mathrm{CN}$ and $\alpha_{\mathrm{s} 1}-\mathrm{CN} / \beta$-CN ratios below 5 and 0.70 , respectively, could be considered not proteolyzed.

\section{Effect of Storage of UHT Milk}

The behavior of proteins during the storage of UHT milk was also considered. It has been previously shown that the electrophoretic patterns of raw and pasteurized milk are similar, whereas those corresponding to UHT milk and milk powder present distorted peaks due to the lactosylation of milk proteins enhanced by the heat processing (Otte et al., 1998; Guyomarc'h et al., 2000). Due to the distortion of peaks, the quantification presented some difficulties. Figure 2 compares two ways of integrating an electropherogram of an UHT milk. In one case, a baseline is drawn under the whey proteins peaks and another one under the rest of the peaks ("straight baseline"). In the other case, the baseline is drawn under the main peaks or peak groups: whey proteins, $\alpha_{\mathrm{s} 2}-\mathrm{CN}$, and some $\gamma-\mathrm{CN}, \alpha_{\mathrm{s} 1}-\mathrm{CN}, \kappa-\mathrm{CN}$, and $\beta$ $\mathrm{CN}, \beta-\mathrm{CN} \mathrm{A}^{1}$, and $\mathrm{A}^{2}$ ("valley to valley").

The comparison of the results obtained with both integration types for whey protein to total protein ratio

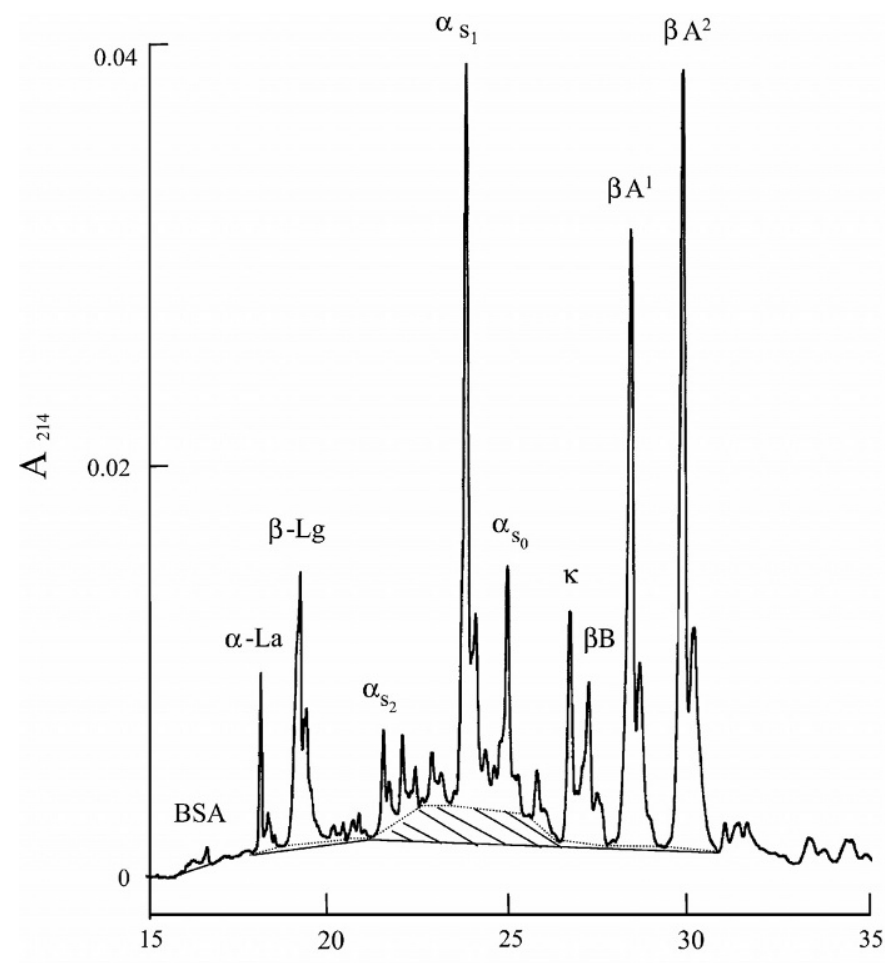

Time (min)

Figure 2. Drawn baselines for integration of the electropherogram of a UHT milk sample.—straight baseline;-valley-to-valley. BSA: Bovine serum albumin, $\alpha$-La: $\alpha$-Lactalbumin, $\beta$-Lg: $\beta$-Lactoglobulin, $\alpha_{\mathrm{s} 2}: \alpha_{\mathrm{s} 2}$-casein $(\mathrm{CN}), \alpha_{\mathrm{s} 1}: \alpha_{\mathrm{s} 1}-\mathrm{CN}, \alpha_{\mathrm{s} 0}: \alpha_{\mathrm{s} 0}-\mathrm{CN}, \kappa: \kappa-\mathrm{CN}, \beta \mathrm{B}: \beta$-CN B, $\beta \mathrm{A}^{1}: \beta-\mathrm{CN} \mathrm{A} \mathrm{A}^{1}, \beta \mathrm{A}^{2}: \beta-\mathrm{CN} \mathrm{A}{ }^{2}$. 
Table 2. Comparison of the determination of the ratio whey protein to total protein in NISECAS reference samples $(15,20$, and $25 \%)$ and samples of UHT milk analyzed by capillary electrophoresis with integration "straight baseline" and "valley to valley."

\begin{tabular}{llllllc}
\hline Samples & $\mathrm{SB}^{1}$ & $\mathrm{VV}^{2}$ & $\begin{array}{c}\text { Average of } \\
\text { differences }\end{array}$ & $\mathrm{SD}$ & $\begin{array}{c}\text { Degrees of } \\
\text { freedom }\end{array}$ & $\begin{array}{c}\text { Significance } \\
\text { (bilateral) }\end{array}$ \\
\hline NISECAS 15 & $15.6 \pm 0.35$ & $16.3 \pm 0.44$ & & & & \\
NISECAS 20 & $21.7 \pm 0.38$ & $22.2 \pm 0.14$ & -0.23 & 0.763 & 17 & $0.22 \mathrm{NS}^{3}$ \\
NISECAS 25 & $26.8 \pm 0.20$ & $27.1 \pm 0.18$ & & & & \\
UHT milks & $13.3 \pm 0.48$ & $15.9 \pm 0.53$ & -2.27 & 0.432 & 5 & $0.00^{*}$ \\
\hline
\end{tabular}

${ }^{1} \mathrm{SB}=$ Integration "straight-baseline".

${ }^{2} \mathrm{VV}=$ Integration "valley-to-valley".

${ }^{3} \mathrm{NS}$ Results not significantly different.

*Results significantly different $(P<0.05)$.

in three reference samples of known whey protein to casein ratio (NISECAS) analyzed in different days and three random samples of UHT milk is shown in Table 2 . Values of whey protein to total protein ratio obtained by integration "straight baseline" were significantly lower than those found by "valley to valley" in UHT milks. In the first case, most peaks were overestimated, especially caseins, giving rise to an underestimation of the whey protein to total protein ratio. However, in the NISECAS, whose peaks are separated to baseline, integration didn't produce any significant difference in the value of the whey protein to total protein ratio. Thus, the shape of the peaks was shown to be crucial for integration. Although a "valley to valley" integration may produce an underestimation of the peak area, in chromatography it is admitted to force the baseline to a valley between two peaks when resolution among them is higher than 1.5 (Guiochon and Gillemin, 1988). These results demonstrated that "valley to valley" was a more accurate way to integrate, therefore further considered the correct way to integrate the electropherograms.

To evaluate the quantitative influence of this integration in the whey protein to total protein ratio obtained by CE, two batches of skimmed milk supplied by different dairy industries (batch 1 and batch 2 ) were analyzed before and after industrial UHT processing. Before the heat treatment the results were $15.6 \pm 0.6$ for batch 1 and $17.2 \pm 0.9$ for batch 2 . After the UHT treatment, the results were $16.3 \pm 0.3$ for batch 1 and $16.2 \pm 0.6$ for batch 2 . The ANOVA analysis $(\mathrm{n}=6)$ found no significant differences $(P<0.05)$ among the whey protein to total protein ratio of milk before and after the UHT treatment.

The UHT milk samples were then stored at room temperature up to $90 \mathrm{~d}$ in order to learn the behavior of proteins during commercial life. Some peaks, which interfered with that of $\beta-\mathrm{Lg}$, appeared upon storage. The analysis of the nitrogen fractions (NCN and NPN) indicated that some proteolytic degradation occurred (results not shown). The results obtained for the whey protein to total protein ratio are shown in Table 3. Significant differences $(P<0.05)$ were found between the whey protein to total protein ratio of recently processed UHT milk samples and those stored during 30 (batch 1) or $60 \mathrm{~d}$ (batch 2). The different behavior could be attributed to a poorer initial microbial quality of milk from batch 1 , in which the proteolytic degradation was higher. Thus, milk proteolysis affected the determination of the whey protein to total protein ratio. To detect samples with proteolysis, the ratios employed for raw milks were calculated (Table 3). The $\alpha_{\mathrm{s} 1}-\mathrm{CN} / \beta$ $\mathrm{CN}$ ratio showed no significant differences $(P<0.05)$ with increasing storage times. This is in accordance with the low residual activity of plasmin on both $\alpha_{\mathrm{s} 1^{-}}$ and $\beta$-CN after the heat treatment of milk (De Koning et al., 1985). On the contrary, the ratio $\alpha_{\mathrm{s} 1}-\mathrm{CN} / \kappa-\mathrm{CN}$ increased during the storage time, the values being

Table 3. Determination of the whey protein to total protein ratio, $\alpha_{\mathrm{s} 1}-\mathrm{CN} / \beta$-CN ratio, and $\alpha_{\mathrm{s} 1}-\mathrm{CN} / \kappa$-CN ratio in two batches of UHT milk stored during $0,30,60$, and $90 \mathrm{~d}$ by capillary electrophoresis $(\mathrm{n}=4)$.

\begin{tabular}{|c|c|c|c|c|c|c|}
\hline \multirow{2}{*}{$\begin{array}{l}\text { Storage time } \\
\text { (days) }\end{array}$} & \multicolumn{2}{|c|}{ Whey protein to total protein ratio $(\%)^{1}$} & \multicolumn{2}{|c|}{$\alpha_{\mathrm{s} 1}-\mathrm{CN} / \beta-\mathrm{CN}$ ratio $^{1}$} & \multicolumn{2}{|c|}{$\alpha_{\mathrm{s} 1}-\mathrm{CN} / \kappa-\mathrm{CN}$ ratio $^{1}$} \\
\hline & Batch 1 & Batch 2 & Batch 1 & Batch 2 & Batch 1 & Batch 2 \\
\hline 0 & $16.3^{\mathrm{a}} \pm 0.3$ & $16.2^{\mathrm{a}} \pm 0.6$ & $0.52^{\mathrm{a}} \pm 0.02$ & $0.54^{\mathrm{a}} \pm 0.01$ & $6.0^{\mathrm{a}} \pm 0.4$ & $4.7^{\mathrm{a}} \pm 0.3$ \\
\hline 30 & $20.4^{\mathrm{b}} \pm 0.4$ & $15.5^{\mathrm{a}} \pm 0.4$ & $0.47^{\mathrm{a}} \pm 0.01$ & $0.44^{\mathrm{a}} \pm 0.04$ & $9.5^{\mathrm{b}} \pm 1.5$ & $4.3^{\mathrm{a}} \pm 0.4$ \\
\hline 60 & $22.0^{\mathrm{c}} \pm 0.5$ & $19.2^{\mathrm{b}} \pm 0.6$ & $0.48^{\mathrm{a}} \pm 0.01$ & $0.46^{\mathrm{a}} \pm 0.05$ & $10.2^{\mathrm{b}} \pm 0.4$ & $6.6^{\mathrm{b}} \pm 1.0$ \\
\hline 90 & $24.0^{\mathrm{d}} \pm 0.3$ & $20.8^{\mathrm{b}} \pm 2.6$ & $0.47^{\mathrm{a}} \pm 0.03$ & $0.49^{\mathrm{a}} \pm 0.06$ & $10.4^{\mathrm{b}} \pm 0.8$ & $8.0^{c} \pm 0.3$ \\
\hline
\end{tabular}

${ }^{1}$ Same letter $(\mathrm{a}, \mathrm{b}, \mathrm{c}, \mathrm{d})$ in the same column means absence of significant differences $(P<0.05)$. 
significantly higher at 30 or at $60 \mathrm{~d}$, as in the whey protein to total protein ratio determination (Table 3). Probably the different number of psychrotrophic bacteria in the milk samples before the heat treatment produced different remnant activity.

The $\alpha_{\mathrm{s} 1}-\mathrm{CN} / \kappa$-CN ratio was calculated in $20 \mathrm{UHT}$ milk samples. The average was $4.7 \pm 1.0$; the quotients were in the range 2.9 to 6.0 . The average $\alpha_{\mathrm{s} 1}-\mathrm{CN} / \beta$-CN ratio was $0.57 \pm 0.05$; the quotients were in the range 0.45 to 0.65 . Thus, the ratio $\alpha_{\mathrm{s} 1}-\mathrm{CN} / \kappa$-CN proved its suitability to detect the proteolysis of an UHT milk, as values higher than 6 would indicate milk proteolysis. Therefore, this CE method is useful for calculating the whey protein to total protein ratio of milk samples unless they have ratios $\alpha_{\mathrm{s} 1}-\mathrm{CN} / \beta-\mathrm{CN}$ and $\alpha_{\mathrm{s} 1}-\mathrm{CN} / \kappa-\mathrm{CN}$ over the cited values.

These results show that the determination of the ratio whey protein to total protein in milk is possible by CE. If samples are affected by a high degree of proteolysis, it is possible to detect them by making a relative measurement of the $\beta$ - and $\kappa$-CN peaks. Therefore, $\mathrm{CE}$ can be considered an alternative method to derivative spectroscopy for the determination of the whey protein to total protein ratio.

\section{ACKNOWLEDGMENTS}

This work was supported by Project AGL-2000-1480 (Ministerio de Ciencia y Tecnologia). B. Miralles was the recipient of a fellowship from the Ministerio de Educaciõn y Cultura. The authors thank J. A. del Prado for technical assistance.

\section{REFERENCES}

Association of Official Analytical Chemists. 1990. Aerobic plate count: Spiral plate method. Page 431 in Official Methods of Analysis. 15th ed. AOAC, Arlington, VA.

Burgess, K. J. 1997. Protein standardization. Int. J. Dairy Technol. $50: 14-18$.

De Koning, P. J., J. Kaper, H. S. Rollema, and F. M. Driessen. 1985. Age thinning and gelation in unconcentrated and concentrated
UHT-sterilized skim milk. Effect of native milk proteinase. Neth. Milk Dairy J. 39:71-87.

Grieve, P. A., and B. J. Kitchen. 1985. Proteolysis in milk: The significance of proteinases originating from milk leucocytes and a comparison of the action of leucocyte, bacterial, and natural milk proteinases on casein. J. Dairy Res. 52:101-112.

Guiochon, G., and C. L. Guillemin. 1988. Quantitative analysis by gas chromatography. Measurement of peak area and derivation of sample composition. Pages 629-659 in Quantitative Gas Chromatography. Elsevier Science Publishers, Amsterdam.

Guyomarc'h, F., F. Warin, D. D. Muir, and J. Leaver. 2000. Lactosylation of milk proteins during the manufacture and storage of skim milk powders. Int. Dairy J. 10:863-872.

International Dairy Federation. 1993. Milk determination of nitrogen content. IDF (FIL-IDF Standard no. 20B).

López-Fandiño, R., A. Olano, N. Corzo, and M. Ramos. 1993. Application of reversed-phase HPLC to the study of proteolysis in UHT milk. J. Dairy Res. 60:111-116.

Lüthi-Peng, Q., and Z. Puhan. 1999. The 4th derivative UV spectroscopic method for the rapid determination of protein and casein in milk. Milchwissenschaft 54:74-77.

Meisel, H. 1995. Application of fourth derivative spectroscopy to quantitation of whey protein and casein in total milk protein. Milchwissenschaft 50:247-251.

Miralles, B., B. Bartolomé, M. Ramos, and L. Amigo. 2000a. Determination of whey protein to total protein ratio in UHT milk using derivative spectroscopy. Int. Dairy J. 10:191-197.

Miralles, B., B. Bartolomé, L. Amigo, and M. Ramos. 2000b. Comparison of three methods to determine the whey protein to total protein ratio in milk. J. Dairy Sci. 83:2759-2765.

Miranda, G., and J. C. Gripon. 1986. [Origin, nature and technological incidences of proteolysis in milk]. Lait 66:1-18.

Otte, J., M. Zakora, K. R. Kristiansen, and K. B. Qvist. 1997. Analysis of bovine caseins and primary hydrolysis products in cheese by capillary zone electrophoresis. Lait 77:241-257.

Otte, J., K. S. Larsen, and S. Bouhallab. 1998. Analysis of lactosylated $\beta$-lactoglobulin by capillary electrophoresis. Int. Dairy J. 8:857-862

Recio, I., and C. Olieman. 1996. Determination of denatured serum proteins in the casein fraction of heat-treated milk by capillary electrophoresis. Electrophoresis 17:1228-1233.

Recio, I., L. Amigo, M. Ramos, and R. López-Fandiño. 1997. Application of capillary electrophoresis to the study of proteolysis of caseins. J. Dairy Res. 64:221-230.

Renner, E. 1988. Storage stability and some nutritional aspects of milk powders and ultra high temperature products at high ambient temperatures. J. Dairy Res. 55:125-142.

Snoeren, T. H. M., R. A. Van der Spek, R. Dekker, and P. Both. 1979. Proteolysis during the storage of UHT-sterilized whole milk. 1. Experiments with heated by the direct system for 4 seconds at $142^{\circ} \mathrm{C}$. Neth. Milk Dairy J. 33:31-39.

Swaisgood, H. E. 1992. Chemistry of the caseins. Pages 63-110 in Advanced Dairy Chemistry. 1: Proteins. P. F. Fox, ed. Elsevier Science Publishers, London. 